\title{
Kongens heder til Mona Skard Heier
}

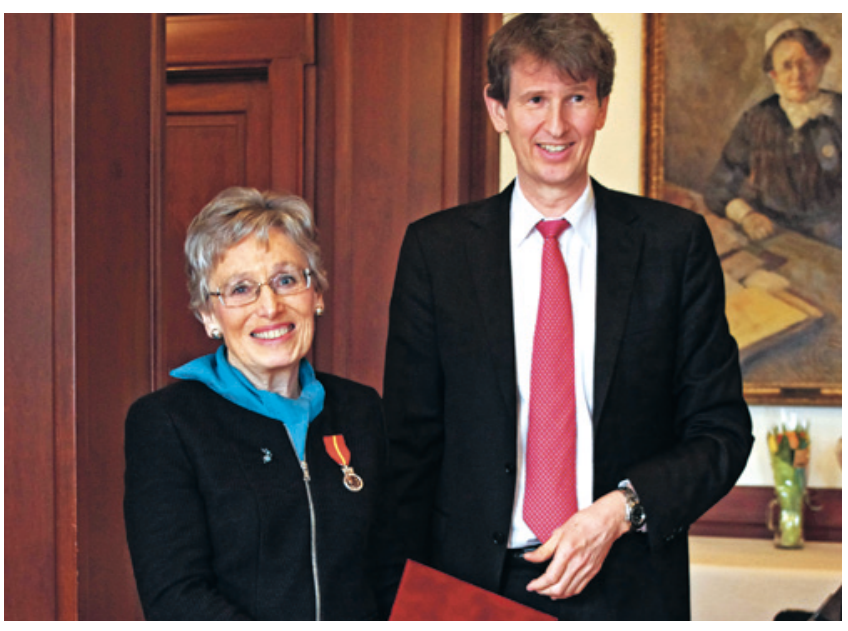

Mona Skard Heier fikk overrakt medalje og diplom av Terje Rootwelt, viseadministrerende direktør ved Oslo universitetssykehus. Foto: Hans Erik Heier
Mona Skard Heier (f. 1939), spesialist i nevrologi og i klinisk nevrofysiologi, er tildelt Kongens fortjenstmedalje for sin innsats for narkolepsiomsorgen i Norge. Medaljen ble overrakt på en mottakelse på Søsterhjemmet på Ullevål fredag 6. mars 2015.

Heier tok medisinsk embetseksamen i Oslo i 1969 og doktorgraden i 1989 med en avhandling om metabolske forhold i sentralnervesystemet med særlig vekt på betydningen av vitamin $B_{1}$.

Hun var tidligere seksjonsoverlege ved Nevrologisk avdeling, Ullevål universitetssykehus, der hun ledet Klinisk nevrofysiologisk laboratorium fra 1989 til 2002. Deretter har hun drevet omfattende forskning og populærvitenskapelig forfatterskap om søvnmedisin, med særlig vekt på narkolepsi. Hun er fortsatt tilknyttet Nasjonalt kompetansesenter for ADHD, Tourettes syndrom og narkolepsi ved Oslo universitetssykehus.

Gunn Marit Seberg

gunn.marit.seberg@legeforeningen.no

\section{Ann-Mari Brubakk ridder av St. Olavs Orden}

\author{
Som den tredje kvinnelige professor i medisin og den første ved Norges teknisk-naturvitenskapelige universitet \\ er Ann-Mari Brubakk utnevnt til ridder av St. Olavs Orden.
}

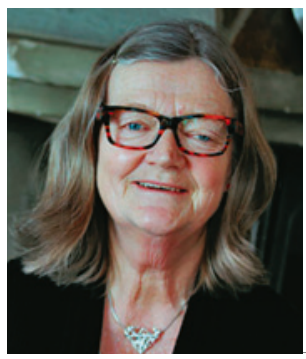

Ann-Mari Brubakk.

Foto: Kjersti Lunden

Nilsen

Overlege ved Barne- og ungdomsklinikken, St. Olavs hospital og professor emerita ved Det medisinske fakultet, Norges teknisk-naturvitenskapelige universitet (NTNU), Ann-Mari Brubakk (f. 1943) ble 23. februar 2015 utnevnt til ridder av 1. klasse av Den kongelige norske St. Olavs Orden. Tildelingen fant sted ved fungerende fylkesmann i Sør-Trøndelag Liv Skjelbred under en høytidelig markering med et stort oppbud av nære kolleger og venner.

Som pediater gjennom mange år er Ann-Mari Brubakks navn uløselig knyttet til faget nyfødtmedisin og feltet for tidlig fødte og svært lavvektige barn. Hun har vært særlig opptatt av gravide kvinners bruk av rusmidler og omsorgen for og oppfølgingen av barn som har vært eksponert for dette i fosterlivet. Klinisk kartlegging av senskader av mødrenes rusbruk med tanke på nedsatt kognisjon og atferdsavvik har stått henne nær. Det har gitt henne den nødvendige kompetansen til å gå kraftfullt inn i arbeidet med å forebygge og gripe inn i problemet.
Brubakk var i lang tid en pådriver for å styrke neonatalmedisin i sin alminnelighet og for opprettelsen av intensivavdelinger i særdeleshet. Blant annet sto hun på for at avdelingene skulle bli bemannet med nyfødtmedisinere $\mathrm{i}$ en fast bakvaktordning.

Gjennom hele karrieren har hun vært opptatt av de aller minste pasientene. Hennes kliniske tilnærming har også gjennomsyret innsatsen som forsker og underviser. Forskningen har vært rettet mot dette ene: Hvordan kan resultatene komme pasientene til gode?

Bruk av dyreeksperimentelle modeller i forskningen har gitt Brubakk inngående kunnskap om skader som kan oppstå ved for tidlig fødsel blant forsøksdyr og mennesker. Hun har også vært en pådriver for å inkludere avansert bildediagnostikk av rotte- og menneskehjerner som støtte for egne hypoteser, observasjoner og slutninger. I første rekke gjelder det bruk av magnetisk resonans (MR).

Brubakk er vel kjent og høyt ansett blant de fleste som utfører forskning på premature barn. Hun regnes som en gründer og er dyktig til å sikre finansiering til prosjekter hun engasjerer seg i.

I utdanningen av leger og annet helsepersonell har Brubakk bidratt med engasjement og bred forståelse. Hun har hatt stor betydning som hovedveileder ved et anselig antall doktorgrader. At det var et lite knippe av hennes tidligere stipendiater som foreslo henne til utnevnelsen, er et talende bevis for hennes innflytelse.

Geir Wenberg Jacobsen geir.jacobsen@ntnu.no 